\title{
Age and Depositional Environment of Walat Formation Based on Palynological Analysis in Sukabumi Regency, West Java, Indonesia
}

\section{Rizki Satria Rachman*, Winantris, Budi Muljana}

Department Geology Engineering, Faculty of Geological Engineering, Padjadjaran University, Bandung, Indonesia, 45363.

*Corresponding author email: rizkisatriarachman@gmail.com

\section{DOI: 10.2478/pjg-2021-0001}

\section{Abstract:}

Walat Formation is equivalent to Bayah Formation. This formation is the beginning of Bogor basin deposition. In this case, age and environment of this formation have been analyzed by previous researchers, but the results of age and environment interpretations have different ranges, especially from its palynological aspect which until now Walat Formation is rarely analyzed using this aspect. This research was conducted to identify the age and depositional environment of Walat Formation in Sukabumi region by using pollen and spores to confirm different interpretations of previous studies. Measure section was carried out in sampling and chemical treatment method was carried out to see palynomorph content in the rock. Furthermore, data analysis was carried out with range of interval zones and pollen grouping based on their environment.

The results show that Walat Formation has Late Eocene age based on the interval zone between first occurrence of Verrucatosporites usmensis and Meyeripollis naharkotensis, and the last occurence of Proxapertites operculatus, Proxapertites cursus, and Cicatricosisporites eocenicus. Walat Formation has fluvial depositional environment characterized by the dominance of Proxapertites operculatus and Proxapertites cursus. The results of this study confirm that the Walat Formation has an Eocene age and a fluvial depositional environment from a palinological aspect.

Keywords: Palynology, Walat Formation, Age, Environment, and Sukabumi

\subsection{Introduction:}

Palynomorph which is studied in the field of palynology is a material that is resistant to acidic substances. This material can be well preserved because of its resistance to destructive factors [1-4]. The examples of palynomorphs are pollen and spores that can be preserved in terrestrial environment to transition and some species can be preserved in marine environment [1,2]. This material has wide and abundant distribution in sedimentary rocks, therefore, pollen and spores can be used as research objects to identify the age and depositional environment of rock formation in an area [5-7].

Walat Formation is located in the Bogor Basin which is equivalent to Bayah formation. This formation is one of the oldest formations in Bogor Basin and became initial key to the formation of this basin [8-13]. The lithology in this formation is alternation between mudstone and quartz sandstone, which at some points contains coal and quartz conglomerates [13,14]. Several studies have led to various interpretations regarding the age and environment of Bayah formation (Figure 1). This formation has been attributed to Eocene - Oligocene age based on geological maps, Early Oligocene age based on palynomorphs such as Florschuetzia trilobata, Monocalpites medius, and Verrumonoletes usmensis spores, Late Eocene age based on foraminifera Grobotalia crozulensiss, and Middle Eocene - Late Eocene age based on nannoplankton conformity [10, 14-18].

Depositional environment of this formation is in terrestrial environment from fluvial section based on rock lithology and nannoplankton conformity, but this formation was interpreted to be in transitional environment drawn based on foraminifera Pyrgo sp. and Rotalia cocoides [10,12,14,18]. 0verall, identification of age and depositional environment was carried out in the Bayah formation, whereas the Walat Formation had not been yet identified its age and environment, especially from palynological analysis.

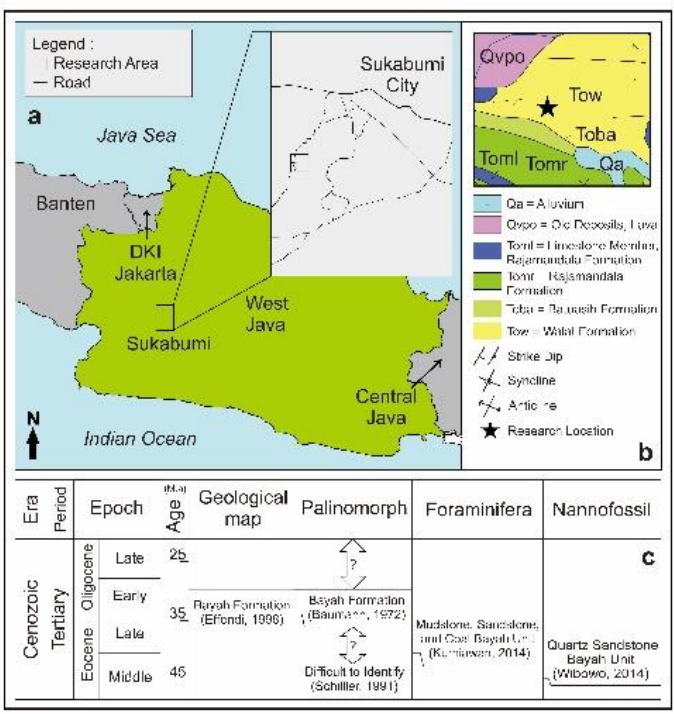

Figure 1: Condition of Research area; a. Research location in relation to West Java, Indonesia; b. Research location in relation to geological map; c. Previous Research of Walat Formation Age

Coordinates of the study area are $06^{\circ} 56^{\prime} 51.52^{\prime \prime}$ South Latitude - $106^{\circ} 51^{\prime} 12.96^{\prime \prime}$ East Longitude to $06^{\circ} 56^{\prime} 28.83^{\prime \prime}$ South Latitude - $106^{\circ} 50^{\prime} 57.93^{\prime \prime}$ East Longitude, Sukadamai village, Sukabumi Regency, West Java, Indonesia. These coordinates were used to obtain the Walat Formation rock layer (Figure 1). 
Since there are different interpretations of age and depositional environment, this study aims to confirm the age and environment of Walat Formation using Palynomorph.

\subsection{Material and Methods}

Field measurements were carried out using measure section method and samples were taken at certain intervals representing the rock layers in study area [19-21]. Furthermore, the samples were prepared using chemical treatment method to separate palynomorphs from other materials [22-25]. This method was done by immersing the sample with various chemicals and neutralizing it with distilled water repeatedly so that the palynomorph material can be

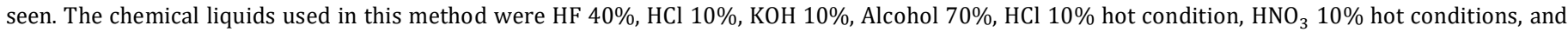
KOH $10 \%$ hot conditions [26-30].

The finished palynomorph slides were analyzed to identify the pollen and spores present on the slide using Olympus CX-22 binocular microscope. Identification and determination of palynomorph material was done by matching characteristics and morphology pollen and spore from some Indonesian palynomorph references and pollen marker [6,31-33]. Afterwards, the identified palynomoph were analyzed to show how the age and environment of Walat Formation [31, 34-39]. The age analysis was carried out by drawing biostratigraphic zones based on age range of pollen and spores present in the study sample, while the depositional environment was done by looking at the dominance of pollen which showed the characteristics of a depositional environment [40-45].

\subsection{Results}

The results of fieldwork revealed various layers of rock with 70 meters thick that have four main lithologies, namely coal, mudstone, very fine - medium quartz sandstones, and quartz conglomerates. At the bottom (old), alternating between coal, mudstone and quartz sandstone with sedimentary structures in the form of Graded Bedding, Organic Matter, and Parallel Lamination are found, while at the top (young) rocks dominated by quartz sandstones to quartz conglomerates with sedimentary structures in the form of Graded Bedding were found (Figure 2).

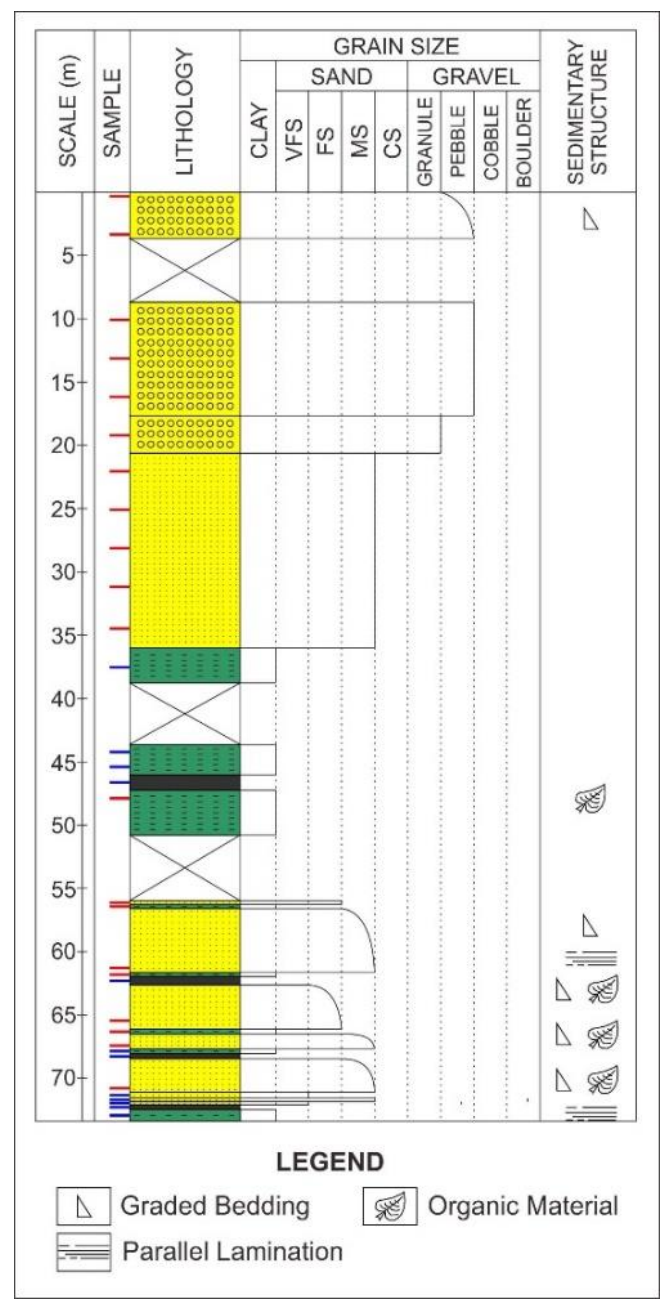

Figure 2: Stratigraphy of the study area. The blue line indicates the presence of palynomorphs, while the red line indicates the absence of palynomorphs

The results of preparation and identification of palynomorphs were found that each sample contained various palynomorph materials. Many research samples did not contain palynomorphs, influenced by the texture of rocks associated with the preservation of palynomorph material on various types of surface rocks. Coal was the sample with the most abundant palynomorph content in this study. From 32 samples prepared (R.1 - R.32), palynomorphs present in 12 samples including R.1, R.2, R.3, R.4, R.5, R.7, R.8, R.12, R.18, R.19, R. 20 , R.21, whereas for other 20 samples, palynomorph was not found (Figure 2).

Palynomorphs in the study sample were very diverse, at least 1049 individuals from 24 types of palynomorphs identified in this study sample. The dominant palynomorphs in this study are Proxapertites operculatus, Proxapertites cursus, Crassoretitriletes vanraadshoveni, and Acrosticum (Table 1). 
Table 1: Palynomorph content of study area

\begin{tabular}{lc} 
Fossil Name & Total Fossil (\%) \\
\hline Proxapertites operculatus & 69.1 \\
Proxapertites cursus & 10.6 \\
Acrosticum & 7.6 \\
Crassoretitriletes vanraadshoveni & 4.5 \\
Laevigatosporites & 2.1 \\
Dicolpopollis sp & 1.1 \\
Verrucatosporites usmensis & 0.8 \\
Pandaniidites & 0.7 \\
Palmaepollenites kutchensis & 0.5 \\
Spinizonocolpites echinatus & 0.5 \\
Florschuetzia trilobata & 0.4 \\
Bacculatusporites & 0.4 \\
Lanagiopollis nanggulaensis & 0.4 \\
Dipterocarpus intricatus & 0.3 \\
Spinizonocolpites prominatus & 0.2 \\
Cicatricosisporites eocenicus & 0.2 \\
Haloragacidites harrisii & 0.1 \\
Myrtaceidites & 0.1 \\
Podocarpidiites & 0.1 \\
Gothanipollis & 0.1 \\
Retistephanocolpites williamsi & 0.1 \\
Meyeripollis naharkotensis & 0.1 \\
Lycopodium cernuum type & 0.1 \\
Apocynaceae type & 0.1 \\
\hline Total & 100.0
\end{tabular}

\subsection{Discussion}

The research samples show many pollens from Eocene and Oligocene age (Figure 3). Important pollen marker in this formation was characterized by the presence of Proxapertites Operculatus, Proxapertites cursus, Cicatricosporites eocenicus, Verrucatosporites usmensis, and Meyeripollis naharkotensis.

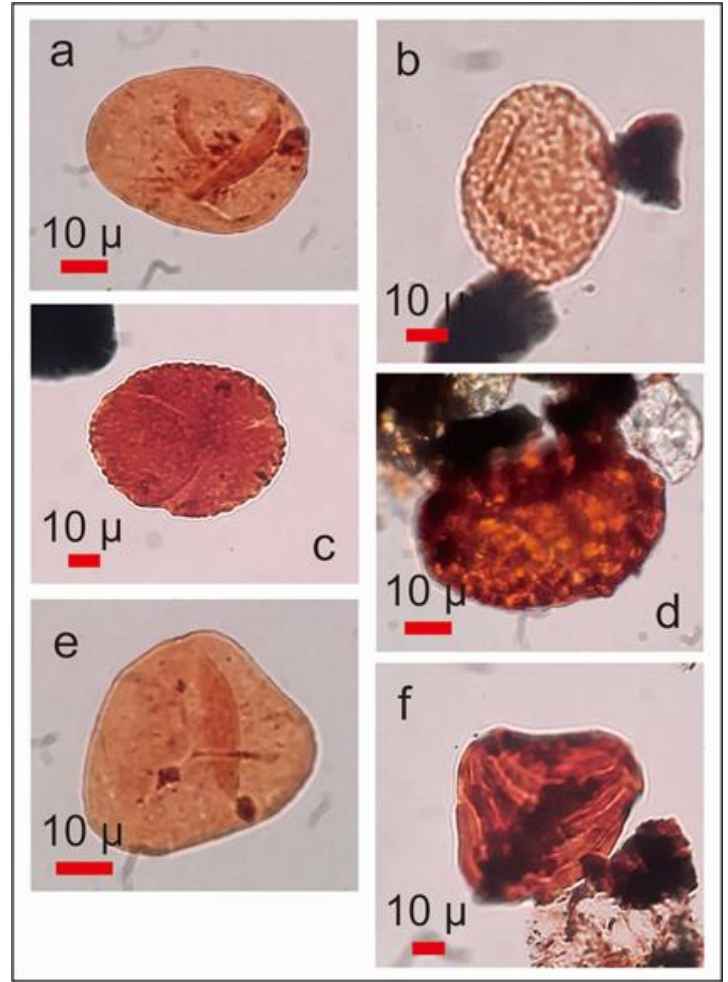

Figure 3: Identified pollen and spores; Pollen (a. Proxapertites operculatus, b. Proxapertites cursus, c. Dipterocarpus intricatus); Spores (d. Crassoretitriletes vanraadshofeni; e. Acrosticum, f. Cicatricosisporites eocenicus)

Basically, age of Walat Formation was identified deposited at Late Eocene age. It was drawn based on interval zone between the first occurrence of Verrucatosporites usmensis and Meyeripollis naharkotensis and the last occurence of Proxapertites operculatus, Proxapertites cursus, and Cicatricosisporites 
eocenicus (figure 4). Then, study sample had a dominance of genus Proxapertites which had appeared in Indonesia at the beginning of Tertiary and became extinct in Late Eocene both species Proxapertites operculatus and Proxapertites cursus.

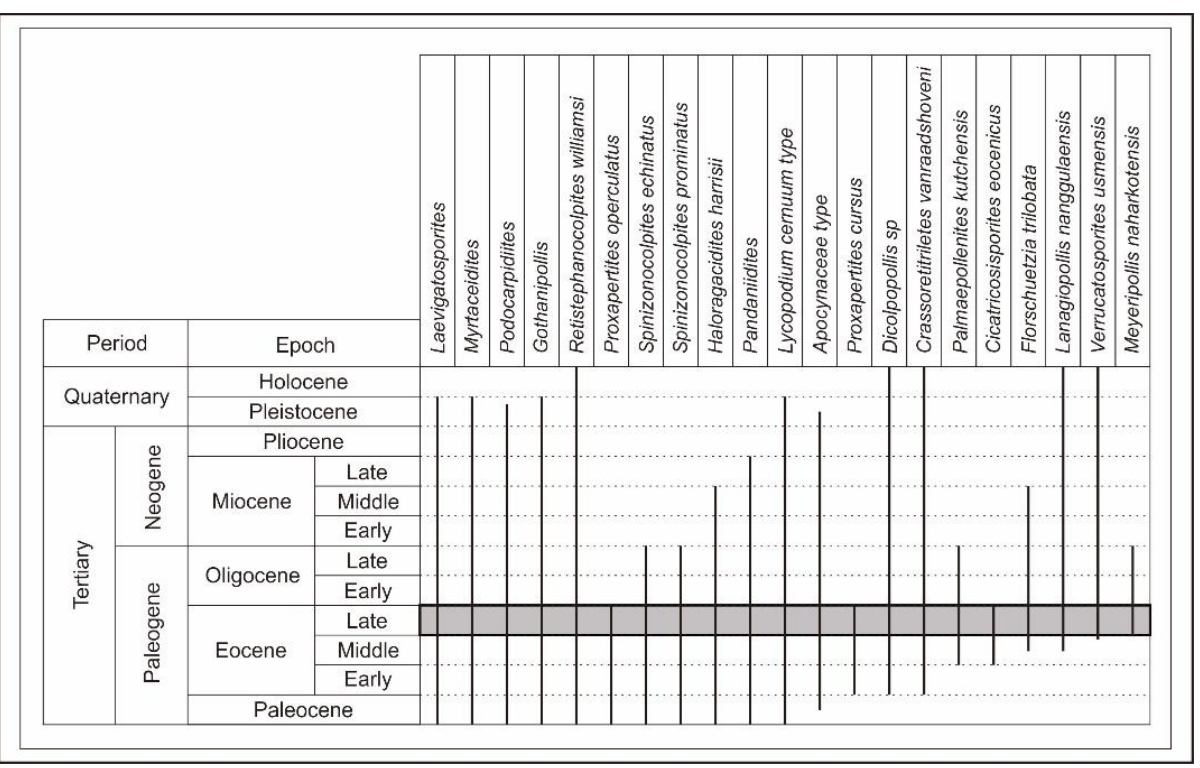

Figure 4: Age of Walat Formation, Late Eocene through the interval zone between the genus Proxapertites, Verrucatosporites usmensis and Meyeripollis naharkotensis $[34,35]$.

From previous studies which stated that the age of the Walat Formation was up to the Early Oligocene, the absence of dominant Proxapertites was identified so that interpretations of Walat Formation continued up to the initial Oligocene [10,15-17]. Meanwhile, Proxapertites were very important palynomorph for Eocene age rocks, because they were extinct at the end of Eocene age. Then, some other studies mentioned this Formation began in the Middle Eocene, whereas, the discovery of pollen Verrucatosporites usmensis and Meyeripollis naharkotensis showed that Walat Formation began to be deposited not far from late Eocene because these two pollens only appeared at Eocene-Oligocene boundary age [14]. Therefore, this study confirms that the walat formation has a tendency to form in late Eocene age when viewed from palinological perspective which is slightly different from previous studies.

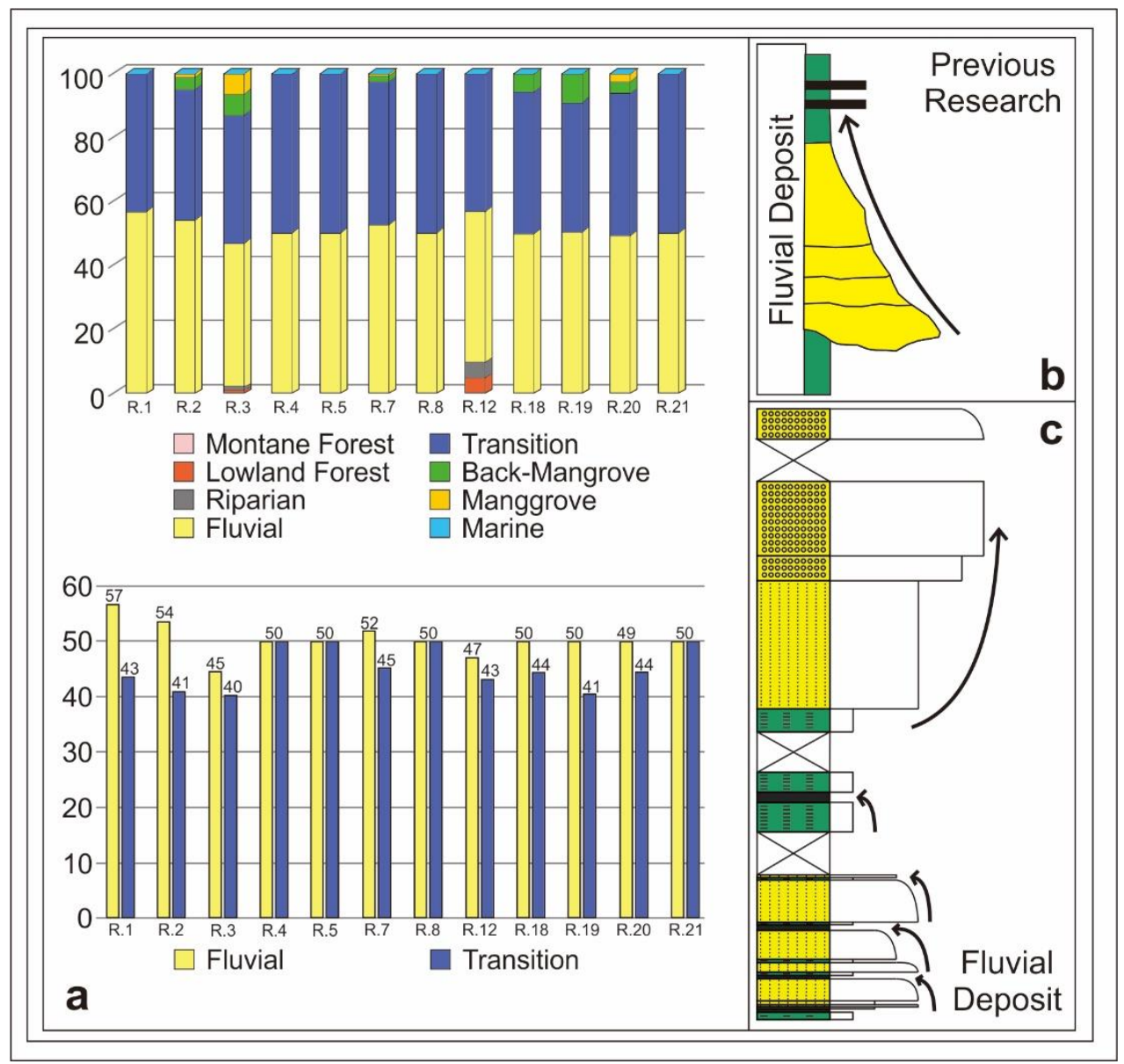

Figure 5: Deposition Environment of Walat Formation; a. Distribution of environment indicative palinomorphs in the study sample [35,46]; b. Lithological characteristics of fluvial deposit from previous research $[13,47]$; c. Lithological characteristics of Walat Formation can be compared to previous research 
The depositional environment of particular formation can be seen from the palinomorph content present in a research sample. Walat Formation was deposited in terrestrial areas as indicated by the absence of marine palynomorphs such as dinocysts or foraminifera lining tests with high pollen and spores from terrestrial areas. From Palynomorph analysis, the graph shows that Walat Formation has tendency of terrestrial depositional environment in fluvial which is characterized by the dominance of Proxapertites operculatus, and Proxapertites cursus, but several samples show that Walat Formation still has influenced pollen from the transitional environment marked by the genus Spinizonocolpites. Whereas in other samples, pollen showed the same amount of transition pollen and fluvial pollen in the study sample (Figure 5). When viewed from characteristics of rocks, Walat Formation has similarity to fluvial deposits from previous research, where lithological characteristics tend to alternating between sandstones, mudstones, and coal [13, 47]. In addition, the presence of graded bedding and parallel lamination sedimentary structures increasingly shows the formation of sediment in the fluvial environment. Therefore, it can be seen that Walat Formation has terrestrial depositional environment region precisely in fluvial environment which is slightly affected by the transition region or close to the transition conditions (Figure 5).

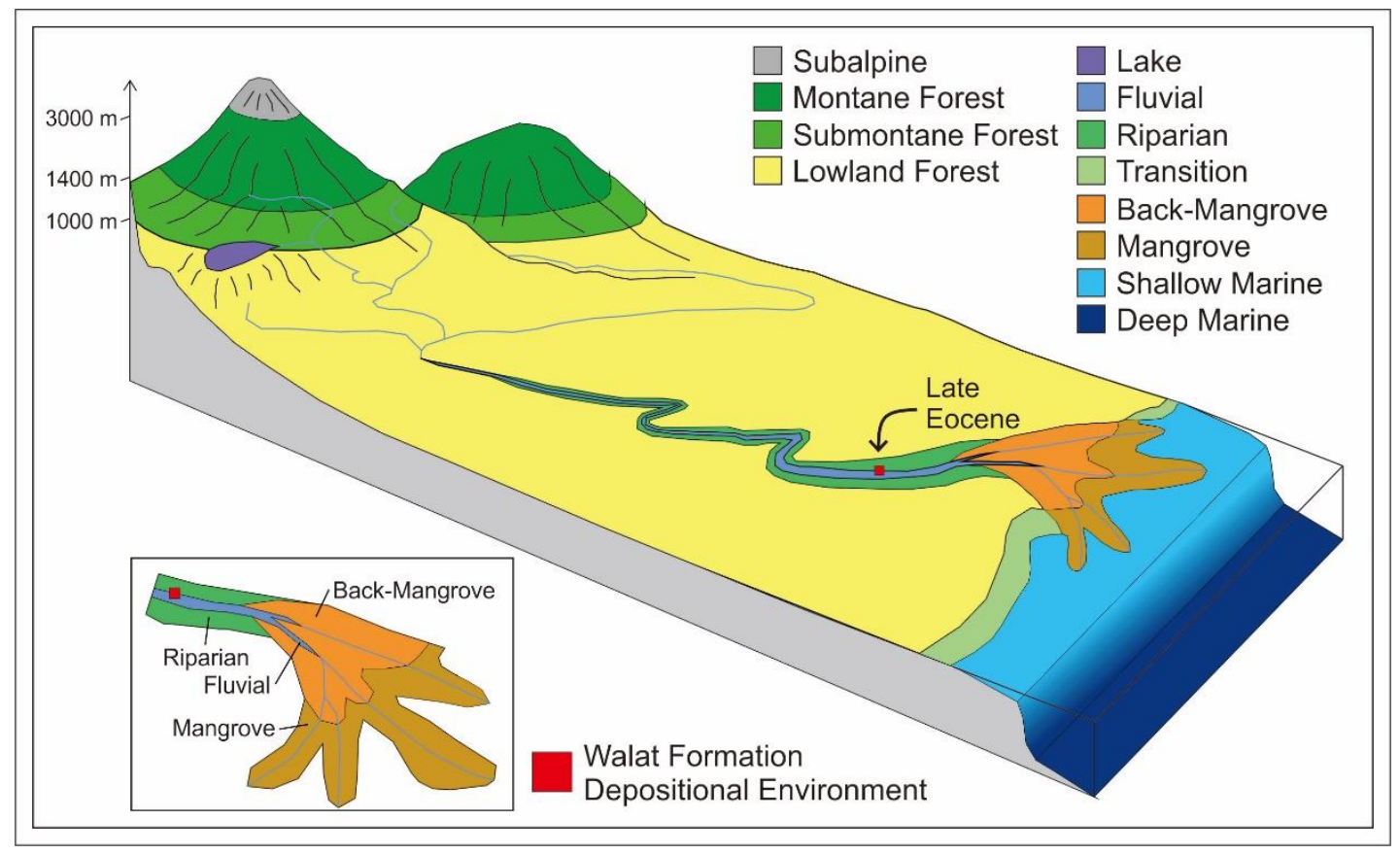

Figure 6: Walat Formation depositional environment model [48]

Some studies suggested that Walat Formation is deposited in a fluvial and transition environment $[10,12,14,18]$. From the results of palynomorph analysis and lithological characteristics, Walat Formation has primary depositional environment at fluvial which is affected by the presence of transition environment or is near the transition environment. Thus, the transition pollen was also found in smaller amounts compared to the pollen originating from the fluvial environment. Therefore, the interpretation of walat formation depositional environment is interpreted to be fluvial which is similar to the results of previous studies using other types of analysis. The location of the depositional environment and age of Walat Formation can be seen in the model (Figure 6).

\subsection{Conclusion}

Walat Formation has rock lithology in the form of alternation between coal, mudstone and quartz sandstone at the bottom, and turned into quartz sandstone and quartz conglomerate at the top with graded bedding, organic matter, and parallel lamination sedimentary structures. Palynomorph analysis shows that Walat Formation is deposited in fluvial environment that is affected by the transition or close to the transition, with Late Eocene age.

\subsection{Acknowledgement}

Thank you to the Chancellor of Universitas Padjadjaran for funding this research through HIU-RKDU program, the paleontology laboratory team of Faculty of Geological Engineering Universitas Padjadjaran, and all those who have contributed to this research.

\subsection{References}

[1] H.A. Hyde, and D.A. Wiliams, "Pollen Analysis Circular”, 8 ed. s.l.:Mimeo, 1944.

[2] G. Erdtman, "Pollen Morphology and Plant Taxonomy”, Hanfer Publishing Company, New York and London, 1966.

[3] A. Traverse, “Paleopalynology”, Unvin Hyman, Boston, 1988.

[4] Jones, Rowe, "Fossil Plants and Spores: Modern Techniques", The Geological Society, London, 1999.

[5] R.V. Tyson, "Sedimentary Organic Matter, Organic Facies and Palynofacies", Chapman and Hall, London, 1955.

[6] A.A. Polhaupessy, "Paleogen-Neogen Pollen from the Nanggulan and Karangsambung Regions of Central Java”, Jurnal Sumber Daya Geologi, Vol. 19, No. 5, Pp. 325-332, 2009. doi:http://dx.doi.org/10.33332/jgsm.geologi.v19i5.216.

[7] K. Anggi, Sukarsa, R. Setijadi, "Paleovegetation Based on Palinological Evidence of the Pliocene Epoch, Banyumas Basin”, Biosfera, Vol. 29, No. 3, Pp. 117, 2012. doi:10.20884/1.mib.2012.29.3.251 
[8] D. Sukarna, S.A. Mangga, and K. Brata, "Geology of the Bayah area: implications for the Cenozoic evolution of West Java, Indonesia", Geological Society of Malaysia, Vol. 33, Pp. 163-180, 1992.

[9] Y. Kusumahbrata, "Sedimentology and stratigraphy of the Bayah, Walat and Ciletuh Formations, Southwest Java Basin, Indonesia", The University Of Wollongong, New South Wales, 1994.

[10] S. Martodjojo, "Evolution of the Bogor Basin, West Java”, Institut Teknologi Bandung, Bandung, 2003.

[11] F. Hasibuan, "Ostrea (Turkostrea) Doidoiensis Hasibuan From The Bayah Formation West Java: A New Find”, Jurnal Geologi dan Sumberdaya Mineral, Vol. 16, No. 1, Pp. 16-29, 2006. doi:p://dx.doi.org/10.33332/jgsm.geologi.v16i1.350.

[12] B. Clements, “Cretaceous to Late Miocene Stratigraphic and Tectonic Evolution Of West Java”, Indonesian Petroleum Association, Pp. 1-18, 2007.

[13] E. Sunardi, and B.G. Adhiperdana, "Sedimentology and Paleohydrology of Oligocene Fluvial Sediment Walat Formation, Sukabumi, West Java", Bionatura, Vol. 15, No. 1, Pp. 8-13, 2013.

[14] U.P. Wibowo, and R. Kapid, “Nannoplankton Biostratigraphy of the Rajamandala Region”, Jurnal Geologi Sumber Daya Mineral, Vol. 15, No. 4, Pp. 185194, 2014. doi:http://dx.doi.org/10.33332/jgsm.geologi.v15i4.57.

[15] D.M. Schiller, “Eocene Submarine Fan Sedimentation In Southwest Java.", Indonesian Petroleum Association, Pp. 125-181, 1991.

[16] Effendi, Kusnama, Hermantos, “Geological Map Sheet Bogor, West Java”, Pusat Penelitian dan Pengembangan Geologi, Bandung, 1998.

[17] P. Baumann, “The Cenozoic of Java and Sumatera. s.l.", Indonesian Petroleum Association, Pp. 31-40, 1972.

[18] E. Kurniawan, T. Syahrulyati, and M. Syaiful, "Geology and Coal Resources of Lebaktipar and Its Surrounding, Cilograng District, Lebak Regency, Banten Province”, Jurnal Online Mahasiswa (JOM) Bidang Teknik Geologi, Vol. 1, No. 1, Pp. 1-14, 2016

[19] F. Hasibuan, “Deposition Environment of Malawa Formation, South Sulawesi Based on Fossil Macro Content”, Jurnal Geologi dan Sumberdaya Mineral, Vol. 19, No. 2, Pp. 95-106, 2009. doi:http://dx.doi.org/10.33332/jgsm.geologi.v19i2.196.

[20] S. Bachri, E. Slameto, I. Nurdiana, "Stratigraphy and Sedimentology of Tidal Plain Deposits in Kali Tulis, Banjarnegara", Jurnal Geologi dan Sumberdaya Mineral, Vol. 20, No. 3, Pp. 169-176, 2010. doi:http://dx.doi.org/10.33332/jgsm.geologi.v20i3.170.

[21] R. Fauzi, "Depositional Environment Study of Balikpapan Formation, Batu Besaung Area. Samarinda”, Prosiding Seminar Nasional Teknologi IV, Pp. 76-80, 2018.

[22] K.A. Moore, and P.D. Webb, "An Illustrated Guide to Pollen Analysis", Holder and Stought, London, 1978.

[23] R. Setijadi, A.T. Rahardjo, "Flora and Vegetation History of Kalibiuk and Kaliglagah Formation at Bumiayu Region, Judging from Palinological Evidence", Universitas Gadjah Mada, Yogyakarta, 2001.

[24] R. Setijadi, "Climate Change in the Pliocene - Pleistocene Region, Bumiayu Region from Palinological Evidence", Dinamika Rekayasa, Vol. 4, No. 2, Pp. 61-64, 2008. doi:http://dx.doi.org/10.20884/1.dr.2008.4.2.114.

[25] R. Setijadi, S.W.A. Suedi, 2011. Diversity of Mangrove Forest Flora in Rembang and Semarang Beaches Based on its Palinological Evidence. Berkala Penelitian Hayati Edisi Khusus, Vol. 7A, Pp. 25-28, 2011.

[26] R. Setijadi, Suwardi, Suedy, and S.W. Agung, "The Dynamics of the Holosen Mangrove Vegetation in the Semarang Regional Area", Dinamika Rekayasa, Vol. 6, No. 1, Pp. 9-13, 2010. doi:http://dx.doi.org/10.20884/1.dr.2010.6.1.28.

[27] Y. Akyol, E. Alcitepe, C. Ozdemir, "The morphological, anatomical and palynological properties of endemic Haplophyllum megalanthum Bornm. (Rutaceae)", Pakistan Journal of Botany, Vol. 44, No. 3, Pp. 1121-1126, 2012.

[28] F. Mikaf, "Morphological Study of Pollen in Several Varieties", Eksakta, Vol. 2, Pp. 99-106, 2013.

[29] N. Azizah, S.W.A. Suedy, and E. Prihastanti, 2016. Plant Diversity Based on Pollen and Spores Morphology from Dieng Warna Lake Sediment, Wonosobo Regency, Central Java. Buletin Anatomi dan Fisiologi, Vol. 24, No. 1, Pp. 66-75, 2016. doi:https://doi.org/10.14710/baf.v24i1.11695.

[30] S. Sarah, S.W.A. Suedy, and E.D. Hastuti, "Morphological Characteristics of Pollen and Spores Plant of Klaten Jombor Swamp Sediment”, Bioma, Vol. 19, No. 1, Pp. 5-12, 2017. doi:https://doi.org/10.14710/bioma.19.1.5-12.

[31] R.J. Morley, "Palynological Evidence For Tertiary Plant Dispersals In The SE Asian Region In Relation To Plate Tectonics And Climate”, Biogeography and Gelogical Evolution Of SE Asia, Pp. 211-234, 1998.

[32] L. Mao, and S.Y. Foong, "Tracing ancestral biogeography of Sonneratia based on fossil pollen andtheir probable modern analogues", Palaeoworld, Vol. 22, No. 3-4, Pp. 133-143, 2013. doi:https://doi.org/10.1016/j.palwor.2013.09.002.

[33] L.C.A. Martínez, S. Archangelsky, M.B. Pramparo, and A. Archangelsky, "Early Cretaceous palm pollen tetrads from Patagonia, Argentina", Cretaceous Research, Vol. 59, Pp. 129-139, 2016. doi:https://doi.org/10.1016/j.cretres.2015.10.023.

[34] R.J. Morley, "Tertiary stratigraphic palynology in Southeast Asia: current status and new directions", Geological Society of Malaysia, Vol. 28, Pp. 1-36, 1991.

[35] E.B. Lelono, "Gondwanan Palynomorphs From The Paleogene Sediments Of East Java: The Evidence Of Earlier Arrival", Lemigas Scientific Contributions, Vol. 30, No. 2, Pp. 1-12, 2007a.

[36] E.B. Lelono, "Palinomorf Eocene of the Makassar Strait", Lembaran Publikasi Lemigas, Vol. 41, No. 1, Pp. 1-10, 2007b. 
[37] E.B. Lelono, "Palynological Investigation Of The Oligocene Sediment In East Java Sea", Lemigas Scientific Contributions, Vol. 30, No. 1, Pp. 7-17, 2007c.

[38] E.B. Lelono, "Zones of Tertiary Pollen in Eastern Indonesia", Lembaran Publikasi Lemigas, Vol. 41, No. 1, Pp. 1-8, 2007d.

[39] R. Setijadi, and E. Rusmiyanto, "Central Miocene Paleodiversity Based on Palinological Data in the Cimandiri Formation of the Cijarian River Sukabumi", Jurnal Ilmiah Dinamika Rekayasa, Vol. 10, No. 2, Pp. 63-67, 2014. doi:http://dx.doi.org/10.20884/1.dr.2014.10.2.85.

[40] J.C. Barry, E.H. Lindsay, and L.L. Jacobs, "A Biostratigraphic Zonation Of The Middle And Upper Siwaliks Of The Potwar Plateau Of Northern Pakistan", Palaeogeography, Palaeoclimatology, Palaeoecology, Vol. 37, Pp. 95-130, 1982. doi:https://doi.org/10.1016/0031-0182(82)90059-1.

[41] K.S.S. Indonesia, “Sandi Stratigrafi Indonesia”, Ikatan Ahli Geologi Indonesia, Jakarta, 1996.

[42] Y. Jianxin, Y. Akira, and K. Kiyoko, "Upper Permian biostratigraphic correlation between conodont and radiolarian zones in the Tamba-Mino Terrane, Southwest Japan", Journal of Geosciences, Vol. 44, No. 5, Pp. 97-119, 2001.

[43] P. Haseldonckx, “A palynological interpretation of palaeoenvironments in SE Asia”, Sains Malaysiana, Vol. 3, Pp. 119-127, 1974.

[44] P. Haseldonckx, "The Palynology of a Holocene Marginal Peat Swamp environment in Johore, Malaysia", Review of Palaeobotany and Palynology, Vol. 24, No. 5, Pp. 227-238, 1977. doi:https://doi.org/10.1016/0034-6667(77)90036-7.

[45] E. Yulianto, "A Holocene pollen record of vegetation and coastal environmental changes in the coastal swamp forest at Batulicin, South Kalimantan, Indonesia", Journal of Asian Earth Sciences, Vol. 25, No. 1, Pp. 1-8, 2005. doi:https://doi.org/10.1016/j.jseaes.2004.01.005.

[46] N.H. Chung, C.D. Quang, and N.T. Tham, "A Review of Tertiary Palynomorph Assemblage in Cuu Long Basin: Case Study of Palynomorphs in Miocene Oligocene Sediments", International Journal of Sciences: Basic and Applied Research (IJSBAR), Vol. 24, No. 3, Pp. 103-111, 2015.

[47] G. Nichols, "Sedimentology and Stratigraphy Second Edition", Blackwell John Wiley and Sons, United Kingdom, 2009.

[48] R.J. Morley, H.P. Morley, Y. Zaim, and O.F. Huffman, "Palaeoenvironmental setting of Mojokerto Homo erectus, the palynological expressions of Pleistocene marine deltas, open grasslands and volcanic mountains in East Java", Journal of Biogeography, Vol. 47, No. 3, Pp. 1-18, 2019. doi:https://doi.org/10.1111/jbi.13770. 